\title{
UPAYA YURIDIS DAN SOSIOLOGIS \\ KANTOR URUSAN AGAMA DALAM \\ PENCEGAHAN PERNIKAHAN USIA DINI
}

\author{
Ahmad Wafiq \\ Staf Kantor Kementerian Agama Kabupaten Bantul \\ F. Setiawan Santoso \\ FAI UCY
}

\begin{abstract}
Because of the strict regulation, the Office of Religious Affairs (KUA) needs to minimize the implementation of early marriage. KUA Jetis sub-district, Bantul Regency has conducted juridical and sociological efforts based on qualitative research organized. Through documentation, observation and interviews with KUA employees and sub-district employees, these conclusions were obtained.

Keywords; Juridical efforts, sociological efforts, prevention, early marriage

Abstrak: Karena Pengaturan yang ketat, Kantor urusan Agama (KUA) perlu meminimalisir pelakasanaan pernikaahan usia dini. KUA kecamatan Jetis Kabupaten Bantul telah melakukan usaha yuridis maupun sosiologis berdasakrkan penelitian kualitatif yang dilakukan. Melalui dokumentasi, observasi dan wawancara dengan pegawai KUA dan pegawai kecamatan, kesimpulan tersebut didapat.
\end{abstract}

Kata Kunci; Upaya yuridis, upaya sosiologis, pencegahan, pernikahan usia dini

\section{A. Latar Belakang}

Kesiapan dalam mengarungi bahtera rumah tangga membutuhkan kematangan diri dari kedua belah belah pihak, baik dari sisi fisik dan psikis. Kegagalan dalam mencapainya bisa berakibat pada terputusnya pernikahan dari harapan yang lebih baik. ${ }^{1}$

Karena akibat yang luas dalam masyarakat, maka perlu Hokum perkawinan Islam di Indonesia. Dalam UndangUndang Nomor 1 Tahun 1974 (UU Perkawinan) tentang Perkawinan. Al Amin mencatat didalamnya terdiri dari 14 bab dan 67 pasalı dan dikemas dalam bentuk pasal-pasal dengan tujuan untuk memberikan kemudahan pemahaman

1 Azis Muslim \& Difla Nadjih,"Analisis Sosiologis Faktor-Faktor Penyebab Perceraian, Studi Kasus Cerai Gugat Di Kecamatan Banguntapan Tahun 2009- 2011," Jurnal Ulumuddin volume 3 nomor 1, Juni 2013, h. 23-34 
pada masyarakat Muslim Indonesia. Kompilasi Hukum Islam (KHI) berdasarkan Inpres No. 1 Tahun 1991 juga berkaitan dengan UU Perkawinan. ${ }^{2}$ Semua itu merupakan bagian hukum materiil yang mengatur perkawinan bagi masyarakat Muslim di Indonesia. Pengaturannya termasuk batas usia pelaku perkawinan.

Dalam Pasal 7 Ayat 1 Undang-Undang No. 1 Tahun 1974 yang mengatakan bahwa "Perkawinan hanya diizinkan jika pihak pria sudah mencapai usia 19 tahun dan pihak wanita sudah mencapai usia 16 tahun"3 Batasan umur dalam Undang-undang telah membatasi dan menekan kejadian dari pelaksanaan perkawinan dibawah umur dalam masyarakat. 4

Praktek dalam masyarakat Indonesia ternyata tidak selalu sesuai dengan peraturan pembatasan pernikahan di bawah umur. Demikian yang disinyalir oleh Irawan. 5 Setiady menyimpulkan kemungkinannya dari sisi hukum adat perkawinan yang berlaku. Perkawinan adat masih tidak membatasi kesatuan kedua belah pihak. Di situ ada penyatuan kedua orang tua dari kedua belah pihak, saudara-saudaranya bahkan keluargakeluarga mereka masing-masing. ${ }^{6}$

undang-undang kemudian memberikan jalan bagi tata laksana perkawinan di bawah umur, meski masih dalam bentuk pengecualian. Hal ini diatur dalam pasal 7 ayat 2 Undang-Undang No. 1 Tahun 1974, yaitu dengan adanya dispensasi dari pengadilan bagi yang belum mencapai batas umur minimal tersebut.

Kantor urusan Agama (KUA) sebagai lembaga yang berada di garis depan dalam pelaksanaan perkawinan secara Islam di Indonesia harus menguasai dan menindaklanjuti aturan batasan umur dalam perkawinan. Aparatnya perlu langkah intensif untuk meminimalisir pelaku di bawah

2 M. Nur Kholis Al Amin, "Perkawinan Campuran Dalam Kajian Perkembangan Hukum: Antara Perkawinan Beda Agama Dan Perkawinan Beda Kewarganegaraan Di Indonesia," Al-Ahwal, Vol. 9, No. 2, Desember 2016 M/1438 H, h. 211-22O

3Hilman Hadikusuma, Hukum Perkawinan Islam Menurut Perundangan, Hukum Adat, Hukum Agama, (Bandung: Mandar Maju,1990), h. 52

4 Ibid.

5 Andrie Irawan, "Harmonisasi Hukum Nasional dan Hukum Islam dalam Mencari Batasan Usia Minimal Menikah bagi Anak," Jurnal Hukum Respublica, Vol. 10, No. 2, h. 247-26o

6Tolib Setiady, Intisari Hukum Adat Indonesia, (Bandung:Alfabeta, 2008), h. 225 


\section{Upaya Yuridis Dan Sosiologis Kantor Urusan Agama}

Dalam Pencegahan Pernikahan Usia Dini

umur. KUA kecamatan Jetis Kabupaten Bantul tidak luput dari tugas tersebut.

\section{B. Metode Penelitian}

Metode yang digunakan dalam penelitian ini adalah metode kualitatif. Bogdan Taylor di Moleong menyatakan penelitian kualitatif adalah sebagai prosedur penelitian yang menghasilkan data deskriptif berupa kata-kata tertulis atau lisan dari orang-orang perilaku yang dapat diamati.7 Kehadiran peneliti ini sangat penting dan utama, seperti yang dikatakan Moleong, bahwa dalam penelitian kualitatif peneliti sendiri atau dengan bantuan orang lain merupakan alat pengumpul data utama. ${ }^{8}$

Sumber data yang digunakan dalam penelitian ini menggunakan sumber primer dan sumber sekunder. Sumber Primer bersumber langsung dari aparat, dokumen dan peristiwa dari KUA sendiri. Sedang Sumber Sekunder berasal dari Buku-buku penunjang yang berkaitan dengan pelaksanaan perkawinan menurut Undang-Undang Perkawinan, menurut hukum adat, dan perkawinan khususnya di bawah umur.

Berdasarkan pandangan di atas, dalam proses penelitian, peneliti menempatkan diri sebagai instrumen sekaligus pengumpul data. Bukan hanya itu peneliti ditemani oleh seorang informan, untuk memudahkan pengumpulan data yang diharapkan. Peneliti menggunakan metode wawancara yang dilengkapi dengan alat tulis dan buku sebagai pencatat data dari informan. Observasi juga dilakukan terhadap dokumen dan amatan peristiwa yang berkaitan

Dalam analisis data ini digunakan teknik yang sesuai dengan jenis data yang ada serta tujuan penelitian, sehingga peneliti menggunakan metode induktif yaitu cara berfikir yang berangkat dari fakta khusus. peristiwa kongkrit itu sendiri merupakan salah satu karakteristik penelitian kualitatif, yang mana pengembangan didasarkan atas data yang ada dengan desain penelitian yang fleksibel sesuai dengan konteksnya. 9

7Lexy J. Moleong, Metodologi Penelitian Kualitatif, (Bandung: Remaja Rosdakarya, 2000), h. 3

8 Ibid. h. 4

9Suharsimi Arikunto, Prosedur Penelitian Suatu Pendekatan Praktek, (Jakarta : PT Rineka Cipta, 2006), hal 15. 


\section{Perkawinan di Bawah Umur}

Setiap perkawinan yang dilakukan oleh calon pengantin berusia di bawah ketentuan undang-undang termasuk dalam perkawinan di bawah umur. Perkawianan antara pria yang belum berusia 19 tahun atau wanitanya belum berusia 16 tahun juga dikategorikan sebagai perkawinan usia dini. Pasal 81 ayat 2 UU No.23 Tahun 2002 tentang Perlindungan Anak menguatkan ketentuan undang-undang perkawinan. Anak adalah seseorang yang belum berusia 18 (delapan belas) tahun dikategorikan masih anak-anak, juga termasuk anak yang masih dalam kandungan, apabila melangsungkan perkawinan tegas dikatakan adalah perkawinan di bawah umur. ${ }^{10}$

Factor Usia memiliki pengaruh pada kematangan calon pengantin dalam mengambil keputusan. Penelitian Byrne dan Shavelson menunjuk kan bahwa seiring bertambahnya usia akan mempengaruhi pola pikir individu dalam pengambilan keputusan. Factor itu berbanding lurus dengan tingkat pendidikan yang juga berpengaruh terhadap tingkat keputusan remaja untuk menikah dini.

Kematangan usia dan pendidikan berdampak pada pemahaman dan penghayatan terhadap manfaat dari perkawinan. Oleh karena itu, Dari beberapa tujuan perkawinan di atas, al-Ghazali membagi faedah perkawinan menjadi lima ${ }^{11}$, yaitu :

1. Memperoleh keturunan yang sah yang akan melangsungkan dan mempertahankan keturunan agar habitat manusia tidak punah dan dunia tidak kosong. Selain itu, pada hakikatnya diciptakannya nafsu seksual pada diri manusia adalah sebagai pendorong tercapainya tujuan tersebut.

2. Penyaluran gejolak nafsu seksual dengan cara yang ma'ruf. Di sini, perkawinan merupakan sarana yang telah ditentukan oleh syariat untuk memperoleh kelezatan dunia sebagai bukti kelezatan ukhrawi. Ketika manusia memenuhi rangsangannya maka ia akan merasakan

10 Irawan, "Harmonisasi Hukum

11 Al-Ghazali, Menyingkap Hakikat Perkawinan; Adab, Tata Cara dan Hikmahnya, Penerjemah : Muhammad al-Baqir, (Bandung : Karisma, 1999), h. 24. 


\section{Upaya Yuridis Dan Sosiologis Kantor Urusan Agama}

Dalam Pencegahan Pernikahan Usia Dini

puncak kelezatan yang tidak ada bandingnya. Tujuan kedua ini berkaitan erat dengan tujuan pertama yaitu memperoleh anak merupakan tujuan manusia sesuai dengan fitrahnya, sedangkan syahwat merupakan faktor pendorong bagi tercapainya tujuan tersebut.

3. Memperoleh ketenangan hati serta memelihara manusia dari kejahatan dan kerusakan. Sebab dorongan syahwat yang semula (sebelum nikah) biasa dilepaskan dengan cara-cara yang dilarang oleh syara', seperti onani, masturbasi dan atau dengan cara melakukan seks bebas dengan berganti-ganti pasangan, maka dengan perkawinan dorongan seks tersebut akan hanya dipenuhi dengan satu pasangan tetap yaitu istri atau suami. Jadi, perkawinan merupakan pencegah timbulnya bencana akibat dorongan syahwat.

4. Membentuk dan mengatur rumah tangga yang menjadi basis pertama dari masyarakat yang besar berdasarkan cinta dan kasih sayang.

5. Melaksanakan kewajiban masyarakat degan cara menumbuhkan kesungguhan dalam mencari rizki penghidupan yang halal, dan memperbesar rasa tanggung jawab.

Kenyataan perkawainan usia dini bisa didorong dengan bermacam sebab. Meski demikian, hal itu bisa dikelompokkan kepada dua jenis. Sebab dari dalam pengantin itu sendiri yang bersifat internal. Sebab lain berasal dari luar diri pengantin yang bersifat eksternal.

Nasution menjelaskan sebab perkawinan dini masih terjadi hingga ada permintaan dispensasi ke Pengadilan Agama (PA). Sebab-sebab itu bisa berasal dari dalam maupun luar anak calon mempelai. Meski demikian, dua sebab itu bisa saling berhubungan. ${ }^{12}$

\section{Sebab dari Anak}

a. Tidak Sekolah

Faktor tidak sekolah ini dapat menjadi faktor terjadinya perkawinan dini dalam dua bentuk. Pertama, anak putus sekolah, baik

12Khoirudin Nasution, Hukum Perdata (Keluarga) Islam Indonesia dan Perbandingan Hukum Perkawinan di Dunia Muslim, (Yogyakarta: ACADEMIA + TAZZAFA, 2009), h. 383 
pada usia wajib sekolah maupun diluarnya. Akibatnya, anak mengisi waktu dengan bekerja. Dalam kondisi sudah bekerja ini, anak tersebut sudah merasa cukup mandiri, sehingga merasa mampu untuk menghidupi diri sendiri.

Kedua, dalam kekosongan waktu tanpa pekerjaan membuat mereka melakukan hal-hal negatif yang salah satunya adalah menjalin hubungan dengan lawan jenis. Hubungan ini tidak menutup kemungkinan mengakibatkan hamil di luar nikah.

b. Melakukan Hubungan Biologis

Seperti disebutkan sebelumnya, tidak sekolah (pengangguran) dapat menjadi salah satu penyebab terjadinya melakukan hubungan biologis dini. Tentu tidak menutup kemungkinan kasus sejenis ini terjadi karena alasan lain.

c. Hamil Sebelum Menikah

Hamil sebelum menikah ini mirip dengan alasan melakukan hubungan seksual layaknya suami dan istri tersebut di atas. Namun tidak setiap melakukan hubungan seksual mengakibatkan kehamilan. Dalam kondisi anak perempuan telah hamil, tentu membuat orang tua merasa terpaksa menikahkan. ${ }^{13}$

\section{Sebab dari Luar Anak}

a. Khawatir Melanggar Ajaran Agama

Maksud khawatir melanggar ajaran agama disini adalah anak menjalin hubungan dengan lain jenis dalam berbagai bentuk: Semua orang tentu takut melanggar agama, hanya saja dalam aplikasinya muncul perbedaan. Dalam kasus ini ada orang tua tidak rela jika anaknya menjalin hubungan dengan lawan jenis tanpa ikatan nikah. Dengan kata lain, menjalin hubungan tanpa nikah termasuk zina. Dalam banyak kasus anak itu sendiri juga berpendirian sama. Dalam rangka mencegah dari pelanggaran inilah muncul nikah dini agar mereka terhindar dari berbuat berzina tersebut

b. Faktor Ekonomi

13Ibid., h. 384 
Alasan ekonomi sebagai faktor nikah dini dapat dilihat dalam dua bentuk. Pertama, ekonomi orang tua yang tidak mendukung anak sekolah. Akibatnya, apa yang telah disebutkan sebelumnya, mungkin bekerja dan merasa mandiri, kemudian nikah, atau menganggur kemudian menjalin hubungan dengan lain jenis yang mengakibatkan kehamilan.

Kedua, alasan ekonomi orang tua menjadikan anak sebagai tumbal untuk menyelesaikan, khususnya anak perempuan. Bentuknya dapat berupa anak gadis sebagai pembayar hutang. ${ }^{14}$

c. Faktor Adat dan Budaya

Maksud adat dan budaya adalah adat dan budaya perjodohan yang masih umum dan terjadi di beberapa daerah di Indonesia. ${ }^{15}$ Biasanya alasannya adalah untuk segera merealisir ikatan hubungan kekeluargaan antara kerabat mempelai laki-laki dan kerabat mempelai perempuan yang memang telah lama mereka inginkan bersama. Alasan inilah yang kadangkadang menyebabkan adanya anak yang masih dalam kandungan telah dijadikan untuk kelak dikawinkan dengan anak sesuatu keluarga, hanya karena terdorong oleh keinginan adanya ikatan kekeluargaan dengan keluarga itu saja. Dan keinginan adanya ikatan kekeluargaan itu sendiri timbul karena ikatan tersebut akan membawa keuntungan-keuntungan bagi kedua belah pihak. ${ }^{16}$

d. Faktor Teknologi

Mudahnya jangkauan TV dan dengan harga pesawat TV yang relative murah pula, seringkali ditemui di layar kaca beberapa tayangan yang menggambarkan mudah dan indahnya kehidupan berumah tangga, padahal para pemirsa seringkali lupa dan terjebak bahwa semua hal tersebut hanyalah sebuah tayangan sinetron yang penuh rekayasa dan bersifat komersial semata. ${ }^{17}$

Apa yang dapat disimpulkan dari sebab-sebab terjadinya kawin dini di atas minimal, bahwa kemiskinan dan pendidikan saling mempengaruhi

14Ibid., h. 385

15Ibid., h. 387

16 Wignjodipoera, Pengantar dan, h. 133

${ }_{17}$ BKKBN Provinsi Jawa Timur, Buku Panduan PLKB/PKB Dampak Perkawinan Usia Dini Bagi Keluarga, (Surabaya: 2009), h.11-12 
terjadinya perkawinan dini. Kemiskinan menjadi salah satu penyebab tidak dapat akses pendidikan dan terjadi pengangguran. Tanpa pendidikan sudah mendapatkan perubahan paradigma dan budaya.

Selanjutnya paradigma statis menjadi salah satu sebab bertahannya budaya dan adat, termasuk budaya dan adat yang tidak prospektif. Pengangguran menjadi salah satu sebab orang berlaku dan berbuat apa saja untuk mengisi waktu, termasuk menjalin hubungan dengan lain jenis. Menjalin hubungan dengan lain jenis mengakibatkan kemungkian terjadinya hubungan seksual. Akibat berikutnya, untuk menyelesaikan masalah yang muncul terjadi nikah dini. Dengan demikian, diharapkan sejak pendidikan dini dapat dijelaskan kejelekan dan kelemahan nikah dini. Demikian juga upaya pencerahan paradigma orang tua amat dibutuhkan untuk memperkecil praktek nikah dini. ${ }^{18}$

\section{Upaya KUA dalam Pencegahan Pernikahan Usia Dini}

Kantor Urusan Agama adalah instansi terkecil Kementerian Agama (kemenag) yang ada di tingkat Kecamatan. KUA bertugas membantu melaksanakan sebagian tugas Kantor Kemenag Kabupaten di bidang Urusan Agama Islam di wilayah kecamatan. ${ }^{19}$ Pencatatan perkawinan Islam merupakan tugas pentingnya. Untuk itu, lembaga juga berkewajiban untuk mencatatkan perkawinan yang sesuai dengan hokum yang berlaku di Indonesia. Bahkan melakaukan upaya-upaya penting agar ketentuan hokum perkawinan Islam berjalan dengan benar. Termasuk di dalamnya adalah pencatatan pernikahan usia dini.

1. Upaya Yuridis

a. Perizinan nikah dari orang tua secara tertulis

Selanjutnya dalam Peraturan Menteri Agama No.11 tahun 2007 Tentang Pencatatan Nikah Bab IV pasal 8, “Apabila seorang calon suami belum mencapai umur 19 (sembilan belas) tahun dan seorang calon isteri belum mencapai umur 16 (enambelas) tahun, harus mendapat dispensasi dari pengadilan”. Pasal-pasal tersebut diatas sangat jelas sekali hampir tak ada alternatif penafsiran, bahwa usia yang diperbolehkan menikah di 
Indonesia untuk laki-laki 19 (sembilan belas) tahun dan untuk wanita 16 (enambelas) tahun. Namun itu saja belum cukup, dalam tataran implementasinya masih ada syarat yang harus ditempuh oleh calon pengantin (catin), yakni jika calon suami dan calon isteri belum genap berusia 21 (duapuluh satu) tahun maka harus ada ijin dari orang tua atau wali nikah, hal itu sesuai dengan Peraturan Menteri Agama No.11 tahun 2007 tentang Pencatatan nikah Bab IV pasal 7 "Apabila seorang calon mempelai belum mencapai umur 21 (duapuluh satu) tahun, harus mendapat ijin tertulis kedua orang tua”. Ijin ini sifatnya wajib, karena usia itu dipandang masih memerlukan bimbingan dan pengawasan orang tua/wali. Dalam format model N5 orang tua /wali harus membubuhkan tanda tangan dan nama jelas, sehingga ijin dijadikan dasar oleh PPN/ penghulu bahwa kedua mempelai sudah mendapatkan ijin/restu orang tua mereka. Lain halnya jika kedua calon pengantin sudah lebih dari 21 (dua puluhsatu) tahun, maka para catin dapat melaksanakan pernikahan tanpa ada ijin dari orang tua/wali.

b. Dispensasi Nikah

Namun untuk calon pengantin wanita ini akan jadi masalah karena orang tuanya merupakan wali nasab sekaligus orang yang akan menikahkan. Oleh karena itu, ijin dan doa restu orang tua tentu suatu hal yang sangat penting karena akan berkaitan dengan salah satu rukun nikah yakni adanya wali nikah.

Pengajuan perkara permohonan dispensasi kawin dibuat dalam bentuk permohonan (voluntair), bukan gugatan. ${ }^{20}$ Putusaannya dari pengadilan berupa penetapan. Salinan penetapan ini dibuat dan diberikan kepada Pemohon untuk memenuhi persyaratan melangsungkan perkawinan. Jika pemohon tidak puas atas putusan pengadilan, maka dapat mengajukan kasasi ke Mahkamah Agung. ${ }^{21}$

Adapun syarat-syarat dispensasi nikah antara lain adalah :

20Ahrum Hoerudin, Pengadilan Agama (Bahasan tentang Pengertian, Pengajuan Perkara dan Kewenangan Pengadilan Agama Setelah Berlakunya UU No. 7 Tahun 1989 Tentang Peradilan Agama), (Bandung : Citra Aditya Bakti, 1999), hal 11.

${ }_{21}$ Mahkamah Agung RI, Pedoman Teknins Administrasi dan Teknis Peradilan Agama, Buku II (Jakarta: 2009), hlm 197-198 
1. Surat permohonan

2. Foto copy surat nikah orang tua pemohon 1 lembar yang dimaterai Rp. 6.00o di kantor pos.

3. Foto copy KTP 1 lembar

4. Surat keterangan kepala KUA setempat yang menerangkan penolakan karena kurang umur.

5. Foto copy akte kelahiran calon pengantin laki-laki dan perempuan atau foto copy sah ijazah terkahir masing-masing 1 lembar yang dimaterai Rp 6.0oo dikantor pos.

Prosedur pengajuan dispensasi nikah :

1. Surat permohonan yang telah dibuat dan ditandatangani diajukan ke Panitera PA, surat permohonan diajukan pada sub kepaniteraan permohonan, pemohon menghadap pada meja pertama yang akan menaksir besarnya panjar biaya perkara dan menulisnya pada Surat Kuasa Untuk Membayar (SKUM).

2. Calon pemohon kemudian menghadap kepada kasir dengan menyerahkan surat permohonan dan SKUM. Ia membayar panjar biaya perkara pada Bank yang ditunjuk PA sesuai dengan yang tertera pada SKUM tersebut, kemudian menyerahkan bukti setor Bank pada kasir PA

3. Calon pemohon kemudian menghadap pada Meja II dengan menyerahkan surat permohonan dan SKUM yang telah dibayar tersebut. Kemudian Meja II memasukkan surat permohoan tersebut dalam MAP Berkas Perkara dan menyerahkan kepada panitera untuk disampaikan kepada Ketua PA melalui panitera.

4. Dalam waktu selambat-lambatnya 1 (satu) hari, Ketua menunjuk Majelis Hakim untuk memeriksa dan mengadili perkara, dalam sebuah penetapan Majelis Hakim.

5. Majelis Hakim kemudian membuat PHS paling lambat 30 hari setelah perkara terdaftar.

6. Berdasarkan perintah Hakim / Ketua Majelis di dalam PHS, Jurusita / Jurusita Pengganti melaksanakan pemanggilan kepada pihak yang mengajukan dispensasi nikah supaya hadir di persidangan pada hari, 
tanggal dan jam sebagaimana tersebut dalam PHS di tempat persidangan yang telah ditetapkan. ${ }^{22}$

2. Upaya Sosiologis

a. Penyuluhan Agama Islam

Aparat KUA tidak bertugas dalam administrasi semuanya. Bidang penyuluhan dan sosialisasi keagamaan termasuk perkawinan Islam juga termasuk fungsi penting sebagian aparatnya. Garda terdepan berada di tanggung jawab Penyuluh Agama Islam. Berdasarkan Keputusan Menteri Agama (KMA) Nomor 79 tahun 1985 bahwa : "Penyuluh Agama mempunyai peranan sebagai pembimbing masyarakat, sebagai panutan dan sebagai penyambung tugas pemerintah”.

Secara lengkap, Penyuluh agama Islam mempunyai fungsi yang sangat dominan dalam melaksanakan kegiatannya, yaitu :

1) Fungsi Informatif dan Edukatif, sebagai dai yang berkewajiban dakwah, menyampaikan penerangan dan mendidik masyarakat dengan sebaik-baiknya sesuai ajaran Islam.

2) Fungsi Konsultatif, yaitu terlibat dalam persoalan-persoalan yang dihadapi masyarakat, baik secara pribadi, keluarga maupun sebagai anggota masyarakat umum.

3) Fungsi Advokatif, tanggung jawab moral dan sosial untuk melakukan kegiatan pembelaan terhadap umat / masyarakat dari berbagai ancaman, gangguan, hambatan dan tantangan yang merugikan aqidah, mengganggu ibadah dan merusak akhlak".

b. Penguatan kerja sama dengan instansi lain maupun tokoh masyarakat

Badan Penasehat Pembinaan Pelestarian Perkawinan (BP4) adalah bagian dari KUA yang lain. Upaya $\mathrm{BP} 4$ untuk menekan laju pernikahan usia dini adalah dengan sosialisasi dampak perkawinan di bawah umur kepada para remaja di wialyah kerjanya. Pengurus BP-4 berupaya memberikan pemahaman bagi generasi remaja terkait pernikahan, sehingga dapat mengambil keputusan yang tepat jika ingin menikah. Usia rata-rata di bawah umur untuk perempuan 16 tahun ke bawah dan laki-

${ }_{22}$ Mukti Arto, Praktek Perkara Perdata pada Pengdilan Agama, (Jogjakarta: Pustaka Pelajar, 2005), h. 59. 
laki 19 tahun ke bawah. "Selain penyuluhan perkawinan seperti ini, biasanya kami menggelar isbat nikah atau pemberian buku nikah kepada mereka yang belum memilikinya dengan cara dinikahkan ulang. Dalam pelaksanaannya Dalam acara ini biasanya juga bekerja sama dengan BKKBN, Pusekemas, Polsek dan UPT sebagai mitra kerja karena melibatkan para siswa.

\section{A. Penutup}

Upaya-upaya KUA Kecamatan Jetis Kabupaten Bantul dalam mengurangi pernikahan usia dini dapat dibagi menjadi dua kategori sebagai berikut:

1. Upaya Yuridis dengan memperketat pelaksanaan pernikahan sesuai Undang-undang. Untuk pengantin catin pria yang belum berusia 21 tahun harus ada izin perikahan secara tertulis dari orang tua. Sedang catin perempuan yang bleum cukup umur harus disertai keputusan Peradilan agama yang memberikan dispensasi pernikahan.

2. Upaya sosiologis, dengan melakukan kerja sama penyluhan dan sosial untuk menanggulangi peningkatan jumlah pernikahan usia dini di masyarakatnya. Kerja lintas sektoral baik dengan intansi pemerintah terkait, lembaga swadaya masyarakat maupun tokoh masyarakat di bangun atas adanya peningkatan yang cukup signifikan mengenai kasus pernikahan dini yang terus meningkat di wilayah Kabupaten Bantul. Semua kegiatan itu bisa dikrodinasikan melalui Penyuluhan Agama Islam atau kegiatan yang diselnggarakan oleh BP4

KUA Kecamatan Jetis Kabupaten Bantul perlu meningkatkan kerjasama dengan Instansi Lintas Sektoral antara lain Pemerintah Desa Pemerintah Kecamatan, Puskesmas Jetis dan Instansi terkait lainnya hingga tokoh masyarakat. Kerjasama itu dimaksudkan untuk penggalakan sosialisasi prosedur ketat pernikahan usia dini.Secara social, pencegahan bahaya pernikahan usia dini bisa diperluas ruang sosialisasinya. Mereka bisa terlibat dalam kampanye bahaya dari pergaulan bebas, reproduksi sehat, maupun bahaya kenakalan remaja, baik yang diselnggarakan oleh lembaga KUA sendiri maupun berkerja sama dengan pihak lain.

\section{Daftar Pustaka}


Abidin, Slamet. Fiqih Munakahat I. Bandung : Pustaka Setia, 1999

Al Amin, M. Nur Kholis. "Perkawinan Campuran Dalam Kajian Perkembangan Hukum: Antara Perkawinan Beda Agama Dan Perkawinan Beda Kewarganegaraan Di Indonesia.” Al-Ahwal, Vol. 9, No. 2, Desember $2016 \mathrm{M} / 1438$ H, h. 211-22O

Ali, Mohammad Daud Hukum Islam; Pengantar Ilmu Hukum dan Tata Hukum Islam di Indonesia, cet. ke-9, Jakarta : Raja Grafindo Persada, 2001.

Arikunto, Suharsimi. Prosedur Penelitian Suatu Pendekatan Praktek, Jakarta: Rineka Cipta, 2006.

Bisri, Cik Hasan. dkk, Kompilasi Hukum Islam dalam Sistem Hukum Nasional, Jakarta : Logos Wacana Ilmu, 1999..

BKKBN Provinsi Jawa Timur, Buku Panduan PLKB/PKB Dampak Perkawinan Usia Dini Bagi Keluarga, Surabaya: 2009.

Daly, Peunoh. Hukum Perkawinan Islam, Suatu Studi Perbandingan dalam Kalangan Ahlussunnah dan Negara-negara Islam, Jakarta : Bulan Bintang, 1988.

Direktorat Jendral Pembinaan Kelembagaan Agama Islam, Bahan Penyuluhan Hukum, (Jakarta: Departemen Agama RI , 2001.

Ghazali. Menyingkap Hakikat Perkawinan; Adab, Tata Cara dan Hikmahnya, cet. ke-10, Penerjemah : Muhammad al-Baqir, Bandung : Karisma, 1999.

Hadikusuma, Hilman. Hukum Perkawinan Islam Menurut Perundangan, Hukum Adat, Hukum Agama. Bandung: Mandar Maju, 1990.

Hoerudin, Ahrum. Pengadilan Agama (Bahasan tentang Pengertian, Pengajuan Perkara dan Kewenangan Pengadilan Agama Setelah Berlakunya UU No. 7 Tahun 1989 Tentang Peradilan Agama), Bandung : Citra Aditya Bakti, 1999

I Doi, A. Rahman. Karakteristik Hukum Islam dan Perkawinan, cet. ke-1, Jakarta : Raja Grafindo Persada, 1996.

Irawan, Andrie. "Harmonisasi Hukum Nasional dan Hukum Islam dalam Mencari Batasan Usia Minimal Menikah bagi Anak,” Jurnal Hukum Respublica, Vol. 1o, No. 2, h. 247-26o

Irawan, Andrie. "Posisi Hukum Agama (Hukum Islam) Dalam Ranah Politik Indonesia," Academy Of Education Journal Pendidikan Pancasila dan Kewarganegaraan Vol. 6 No.1, Januari 2015, 65-7,

Mahkamah Agung RI, Pedoman Teknis Administrasi dan Teknis Peradilan Agama, Buku II Jakarta: 2009.

Muhdlor, A. Zuhdi. Memahami Hukum Perkawinan: Nikah, Talak, Cerai, dan Rujuk menurut Hukum Islam UU Nomor 1 Tahun 1974 Bandung : Al Bayan, 1994.

Muslim, Azis \& Difla Nadjih,“Analisis Sosiologis Faktor-Faktor Penyebab Perceraian, Studi Kasus Cerai Gugat Di Kecamatan Banguntapan Tahun 2009- 2011," Jurnal Ulumuddin volume 3 nomor 1, Juni 2013, h. 23-34.

Moleong, Lexy J. Metodologi Penelitian Kualitatif. Bandung: Remaja Rosdakarya, 2000.

Muslim, Azis \& Difla Nadjih,“Analisis Sosiologis Faktor-Faktor Penyebab Perceraian, Studi Kasus Cerai Gugat Di Kecamatan Banguntapan 
Tahun 2009- 2011," Jurnal Ulumuddin volume 3 nomor 1, Juni 2013, h. 23-34

Arta, Mukti Praktek Perkara Perdata pada Pengadilan Agama. Jogjakarta: Pustaka Pelajar, 2005.

Nasution, Khoirudin. Hukum Perdata Keluarga Islam Indonesia dan Perbandingan Hukum Perkawinan di Dunia Muslim. Yogyakarta: ACADEMIA + TAZZAFA, 2009.

Shabbagh, Mahmud. Tuntunan Keluarga Bahagia Menurut Islam. cet. ke-3, Bandung : Remaja Rosdakarya, 1994.

Undang-Undang Republik Indonesia No. 1 Tahun 1974 tentang Perkawinan dan Kompilasi Hukum Islam. Bandung:Citra Umbara, 2007. 